\title{
2
}

\section{Painting Outside the Lines: Transgressing the Managerial University, Avoiding Forced Creativity}

\author{
Stephen Leitheiser, Rubén Vezzoni, \\ and Viola Hakkarainen
}

\section{Introduction}

"The act of creation is, I have said, the same in science as in art. It is a natural, human, living act” (Bronowski, 1968). Jacob Bronowski arrived in Nagasaki in 1945 as a mathematician who had worked to develop efficient British bombing strategies during World War II. After being sent to document the destruction following the dropping of the atomic bomb with a team of fellow scientists, he left Nagasaki as a humanist philosopher who would go on to devote his remaining career to foregrounding the importance of human-created values in science, and the fundamental connections between imagination, science, and the arts (Bronowski, 1956; Bronowski et al., 1964). Seeing the wreckage to which his field

\author{
S. Leitheiser $(\varangle)$ \\ University of Groningen, Groningen, The Netherlands \\ e-mail: srleitheiser@protonmail.com \\ R. Vezzoni · V. Hakkarainen \\ University of Helsinki, Helsinki, Finland
}


of scientific work had contributed, Bronowski was faced with the reality that science is not a purely mechanical, neutral, or indifferent collection of observed facts. Instead, he would come to understand science as a creative and imaginative system of knowledge, underpinned by human values, with a blurred, rather than clear-cut line between production and use. Deeply affected by his experience in Nagasaki, Bronowski experienced first-hand the danger of disconnecting science from human values and judgement. He would come to argue that, in achieving its greatest discoveries and usefulness, science had always been humanistic. For Bronowski (1985), science at its best was (1) anti-authoritarian, (2) rooted in human experience, and (3) interconnected with and immersed in nature. It was only when scientists, and more importantly the institutional wholes of which they were part, lost touch with these value-based roots that science could become a "bag of tricks" deployed in the service of a callous bureaucracy intent on preserving its status quo (ibid., p. 264).

Bronowski's story illustrates the complex interaction of lived human experience with subjectivity and understanding of science. It shows the dynamic interplay of experience, values, and worldviews, and in turn, how this shapes approaches to scientific inquiry. This interplay marks the difference between whether one views science as a mechanical set of indifferent facts, or something that is creative, informed by values and context, and conditioned by its use. Just as our human values influence the ways in which we seek to understand the world through science, reason and the things we learn about the world through the scientific method also influence our values and particular normative valuations and prescriptions (Sayer, 2011).

The main theme of this collective book, creative methods (CMs), represents an attempt to contribute to critical discussions about how the process and pursuit of research may be more conducive to (1) making people question established ways of thinking and acting, and (2) building a more inclusive approach to research in which unheard voices are empowered (see Franklin, this book). However, as an approach to conducting research and exchanging knowledge, CMs, just like any other methods, are embedded into human value systems that influence how they are used to produce knowledge, and how that knowledge will be applied (or not applied) in practice (Harré, 1981; Longino, 1990). 
Here we wish to highlight the reflexive character of scientific investigation, which is particularly prominent in the case of humanistic and social sciences. The personal beliefs, motivations and expectations of the researchers play a role in determining what gets discovered and for what purpose, e.g., what kinds of questions are asked and what kind of evidence counts as valid to confirm a hypothesis, across disciplines. Value assumptions, whether epistemic, moral, or political, shape the content of science and its application. Yet this normative shaping of scientific inquiry does not end with the individual researcher, but is mediated through the wider social environment (Sayer, 2011). In particular, we contend that the content and application of science in society is influenced by the institutions that employ researchers and the funders that provide the basis for their material existence. Therefore, a critical discussion of CMs would be incomplete without a structural analysis of the values embedded into the wider contextual environment in which CMs emerge: university systems that are increasingly managerial (Deem et al., 2007; Leišyte, 2015; Shepherd, 2018).

Managerialism is an ideology that is predicated on the universalized application of private sector values and practices, and namely corporatestyle management, into all spheres of society (Chauvière \& Mick, 2013; Deem, 2001). Management becomes "hyper-management" in which "management, as a form and as a process, becomes an end in itself, a self-serving entity" (Barberis, 2012, p. 327). Applied in a university setting, managerialism "colonizes" (Klikauer, 2015) the values traditionally associated with higher education (e.g., truth, autonomy, democracy, or the public good) (Giroux, 2010). Below, we outline what we identify as the main values of the managerial university that are sustained through four major driving forces: an environment of funding scarcity; a logic of competition to secure funding; the implementation of accountability metrics to rank competitors; and the creation of incentives for obedience. First, however, a few disclaimers. We acknowledge that managerialism is not a uniform blueprint, but is rather a pattern in which a more general organizational approach has been applied in various local contexts across the globe (Deem, 2001; Pusser et al., 2011). Nor is the managerial ideology ubiquitous among all academic staff (see, e.g., Connell, 2019). Nevertheless, its system of ideas, ideals, manners, and thoughts has 
been applied by many sitting in influential positions, and mediates academic work, even for those individual academics who may work to resist (Anderson, 2008; Evans, 2020). Finally, we have nothing against management as such, just hyper-management, where its application is counter-productive or inappropriate.

The aim of our critique is to point to how the values and practices of managerialism embedded into universities place inherent constraints on those wishing to bring creativity — as in originality and imaginationinto the academic process, regardless of whether it is in the research process itself or in its application. Moreover, as many researchers who are interested in CMs may also be motivated to achieving transformative real-world outcomes (to fostering, e.g., sustainability, resilience, etc.), we wish to highlight the tremendous uphill battle that they may face within the confines of managerial universities. We do not do this to promote feelings of hopelessness, but rather to shed illusions, and warn about the ever-present danger of co-option. This applies even in the case of novel research approaches that may, on the surface, appear to be different and subversive, of which CMs are an illustrative example. Bringing in creativity may just as easily be used to affirm the status quo as to challenge it (Mould, 2018). By highlighting the managerial university's constraints, we wish to motivate strategic thinking for political action and coalition building outside of and beyond academic work. This chapter provides the analytical grounds from which collective practices can derive strength and cohesion. However, our reflections do not fall in the binary trap "don't act, just think". Beyond provocative statements à la Slavoj Žižek, our approach is more that of Noam Chomsky, who in a recent interview suggested to "look around, analyse the problems, ask yourself what you can do and set out on the work!". ${ }^{1}$ Our task in this chapter is to organize our analysis of the problems, and motivate ourselves and others to reflect on possibilities for action.

If one views individual researchers who use CMs as painters who sketch out original and imaginative ways of approaching and disseminating research, our chapter provides an analysis of the canvas on which

\footnotetext{
${ }^{1}$ Interview by Zeit Campus, 14 June 2011.
} 
they are painting: university institutions. We argue that the managerial university is not a blank canvas on which creativity can be painted. Rather, the canvas of managerialism is defined by a particular set of values that discourages painting outside the lines. In other words, managerialism produces structural impediments to CMs (Bullen et al., 2004; Connell, 2019). Failure to recognize that CMs are simply tools, free to be co-opted and stabilized into this restrictive context, may amplify the latent risk of CMs being reduced to a nice-sounding bag of tricks, that reinforces the status quo under a new coat of paint. We call this latent risk the danger of "forced creativity", 2 of which we provide two illustrative examples: "artwashing" and "funding tricks". We do not wish to suggest that these dangers are particularly unique to CMs as such. Similar challenges are certainly faced by a variety of heterodox thinkers who wish to generate new approaches in science and higher education, or even to hold onto old traditions (Brown, 2010). Our contribution also aims to contribute to this wider discussion, and debates on the role of the university in society. However, in this context of this book, we wish to use the example of CMs to illustrate that even those approaches that may appear to be novel and radical are not inherently resistant to the managerial university's distorting influence. We contend that CMs will only be truly creative to the extent that they are able to resist the trends of the managerial university, which aim to co-opt and appropriate their heterodoxy or stabilize their transformative character. If researchers truly wish to address power relations in the research process, give a voice to the voiceless, and break free from the shackles of the strictly positivist paradigm in social sciences, their efforts must be extended beyond the processes of data collection and dissemination of research, and towards building wider coalitions to intervene in technocratic and managerial takeover.

The chapter begins with an historical context that has contributed to the institutionalization of these managerial values in universities across the globe, after which we outline the values of the managerial university (accountability, competition, and obedience) that find fertile ground 2 The inspiration for this concept comes from Graeber (2018) who uses the term in his book
Bullshit Jobs. 
in an environment of funding scarcity. Next we move on to define our understanding of forced creativity and give two illustrative examples. We suggest that those interested in CMs also bring creativity into the transgression of established academic protocols that bring about the risks of forced creativity.

\section{The Managerial University and the De-Politicization of the Public Sphere}

The Western university as an institution has its roots in the millenary field of political philosophy (Arendt, 1958; Wolin, 1960). In this traditional understanding, the political is an open public realm in which a plurality of possible visions for organizing social and ecological relationships are formed; contested and debated, and contingently agreed upon and institutionalized (Swyngedouw, 2018). The pluralistic character of healthy democratic politics is nurtured by the diversity of interpretations of social existence. Forms of governance can be said to be democratic to the extent that they allow this diversity to thrive. Although dissent may always be challenged, it is never suppressed. The space where this process of political deliberation occurs has traditionally been referred to as the "public sphere" by democratic theorists (e.g., Habermas, 1990): a domain of civic thought and normative discussion on matters of general interest that is separate from both the state and the market (Holmwood, 2017). The public sphere as such is a political space that cannot be reduced to purely rational, technical, or scientific calculations (Arendt, 1958; Mouffe, 2005). It is the space in which meaning, social difference, normative thought, and science enter into a collective process of making sense of the world, evaluation, and prescription. Surely, this ideal has not always existed in practice throughout history, and relationships of power have always determined the conditions and constraints of debate in the public sphere and in the academy (Mouffe, 1992; Tierney \& Lechuga, 2005). That being said, the university has, in different times and places throughout history, been a stronghold in the process of democratizing society (Deem \& Eggins, 2017; Giroux, 2009; Tierney \& Lechuga, 2005). Throughout the twentieth century, however, 
several philosophers began to warn that such public spaces for distinctly political thought-e.g., plurality, dissent, and open debate on matters of general interest-were becoming increasingly narrowed in society at large (Arendt, 1958; Bronowski, 1956; Wolin, 1960). As autonomous and free inquiry are a central component of an open democratic society, universities were a major part of this closure (Giroux, 2009; Holmwood, 2017).

Managerialism draws many similarities with Taylorism, Fordism, technocracy and other traditions of techno-scientific standardization and social homogenization, which of course did not begin in university institutions (see, e.g., Scott, 1998 for a broader, more detailed historical perspective). Here, we trace the modern origins of the managerial ideology into institutions of higher education back to the early twentieth century in the United States, where in the 1910s, an intense debate was waged over educational reform. David Snedden's social efficiency approach (rooted in vocationalism and the production of obedient workers for the capitalist economy) was here pitted against John Dewey's liberal approach (rooted in a desire to create free citizens empowered by independent thought) (Labaree, 2010). The social efficiency approach saw education as a form of training-"something like filling a vessel with water", or imparting pre-existing knowledge on passive subjects (Chomsky, 2012, p. 56). The liberal approach, on the other hand, saw education more like the nurturing of a tree, or "providing the circumstances in which the normal creative patterns will flourish" (ibid.). While Dewey's name and approach may be more recognizable in the present day, Snedden's social efficiency approach would go on to be much more influential in shaping education policy for the remainder of the twentieth century (Labaree, 2010). In the context of a rising working class consciousness at the end of the nineteenth century and early twentieth century (Chomsky, 2012; Goodwyn, 1978; Ware, 1929), Snedden's approach resonated strongly with the powerful coalition of state and capitalist elites. Not only did they view social criticism and moral and political philosophy of the liberal approach as a threat to the status quo, they were also keen to have the burden of training obedient workers covered by public subsidy (Labaree, 2010). This also helps to explain the trend of prioritizing STEM (science, technology, engineering, and 
mathematics) subjects vis-à-vis humanities (namely moral and political philosophy) in many university institutions (Palumbo \& Scott, 2018).

In the post-World War II era, the social efficiency model for the university was increasingly globalized. Managerialism moved beyond the United States, as universities became increasingly viewed as tools for driving global economic development in the broader context of the Cold War and European reconstruction (Adler et al., 2007; Palumbo \& Scott, 2018; Schrum, 2012). During this time, the Rockefeller, Carnegie, and Ford Foundations partnered with the American state to steer the evolution of universities in the so-called developing world ${ }^{3}$; this effectively established a relationship of dependency and instituted a global system of training (rather than education) in line with metropolitan development (Connell, 2019). Business schools rose to power in universities around the world, and an administrative and behavioural approach to social science became more and more hegemonic (Pettigrew et al., 2014; Schrum, 2012). Approaches that foregrounded human values and judgement, creativity and imagination-e.g., liberal arts, or moral and political philosophy-were therefore displaced by a quest to systematically model human behaviour with unified general theories, based on (a perversion of) physical sciences (Klikauer, 2015; Schrum, 2012; Wolin, 1960). According to Wolin (1960), the expansion and fragmentation of social science into disparate disciplines throughout the nineteenth and twentieth centuries was predicated on an eclipse of moral and political philosophy: "While one flourishes, the other flounders in uncertainty of what, if anything, constitutes its subject-matter" (p. 288). As social sciences became increasingly separated and siloed, i.e., into categories of sociology, economics, psychology, etc., and detached from philosophy they also began to distance themselves from the normative critiques that had been attached to positive description in social sciences during (and before) the Enlightenment (Sayer, 2011). Moreover, evaluation and judgement became largely taboo for (social) scientists in

\footnotetext{
3 We emphasize "so-called" here in order to distance ourselves from the normative view that depicts most of the world's countries as lacking "development" and celebrates the progress achieved by relatively few countries that has come at the expense of negative environmental and social externalities that are mostly experienced by those living in other parts of the world (see also Gibson-Graham et al., 2013).
} 
general (ibid.). This included the evacuation of meaningful critiques of dominant (corporatist) ideologies (Chomsky, 2000), and debates over the fundamental role that universities should play in society (Deem \& Eggins, 2017; Pusser et al., 2011). Consequently, foundational dissent has to a great extent been marginalized in wider public debates, with the academy positioned as a central node in the military-industrialacademic complex (Giroux, 2015). In light of this history, we understand the managerial university as a prime contributor to de-politicizing the public sphere and stabilizing the status quo.

As anticipated in the introduction, knowledge creation is not a valuefree process and the society-science relationship is not linear (Turnhout, 2018). Since science does not exist above and outside of society, science qua institution can also not be said to be completely politically neutral. As in a jury trial, the role of scientific expertise is to augment and sharpen democratic, ethical and political discourse through technical fact-finding and bias mitigation; it is not to give a fixed decision-making blueprint to a passive population (Follett, 1930; Hansson, 2004). On the contrary, in political debates science can (and should) inspire a democratic discussion of what constitutes the most desirable direction (Sayer, 2011). The democratic character of discourse is amplified by the extent to which different interests are taken into account, including that of those generations yet to be born or of non-human species. Scientific findings can elucidate this multiplicity of positions and augment our collective intelligence.

The unwillingness to recognize the political aspects that influence the institution of science paradoxically expose it to appropriation by those in relative positions of power in society. Following Bronowski's definition of science laid out above, higher education and research (and the university by extension) cannot be truly scientific without being antiauthoritarian; that is, maintaining an environment of radically open and critical thought, using different lenses and approaches to investigate truth in understanding society and its relationship with the natural world, and exploring the possibilities for alternative ways of thinking about and organizing socio-natural relationships (cf. Deem \& Eggins, 2017). In this sense, science can be seen as a "deeply democratic principle, since it rejects all claims to absolute certainty and insists on open, undominated 
dialogue as the basis for correcting errors and advancing knowledge" (Wright, 2006, p. 94). The difference between these formulations of science and dogmatic scientism is the capacity to critically engage with the ideologies and values of the wider social environment that guide and mediate scientific inquiry (Chomsky, 2008; Popper, 1979). In the case that institutions of knowledge production fail to embody open democratic principles, they run the risk of propagating a mythical science (i.e., anti-scientific scientism), which — as the sole and infallible arbiter of truth that can objectively conduct human decision-making from the outside — can be contorted to suit the whims of powerful agendas: e.g., we [the people] have no choice but to do $X$, because Science has told us [the techno-managerial elite] $Y$. In short, science can also become the "bag of tricks" Bronowski (1985) has warned us about above: deployed in the service of a callous bureaucracy in order to narrow the spectrum of valid thought and debate in the public sphere.

A failure to recognize these risks becomes more problematic as researchers are increasingly called to engage in real world processes to facilitate the application of scientific knowledge and address the wicked and complex problems that humanity is currently facing (e.g., climate change, the destruction of the biosphere, peak oil and peak soil, global inequality) (Blythe et al., 2018). In this socio-environmental context, there is an increasing need for researchers to develop the philosophical underpinnings of action-orientated knowledge production while being able to produce actionable knowledge (Nagatsu et al., 2020). This necessitates that researchers challenge their own biases and assumptions related to global changes. It also includes insulating science per se from perversion by the same forces that may be driving such problems (Shrivastava et al., 2020). These issues have been brought into the spotlight in several fields of research, including, e.g., sustainability science (see e.g., Clark, 2016; Kates et al., 2001; Miller, 2013), in which the position of researchers as detached and objective observers of facts is already well established as false (Wittmayer \& Schäpke, 2014). In this context, many researchers are increasingly reflexive to the implications of their own positionality and the normative stances they imply in the pursuit of actionable knowledge (Hölscher et al., 2017; Wittmayer \& Schäpke, 2014). However, even in fields of research that would ideally carry this 
reflexive awareness, attempts to escape the de-politicized landscape of the public sphere have been unsuccessful (Nagatsu et al., 2020). For example, Fazey et al. (2018) point out that although the need for transformative research is recognized, the majority of resources and attention are directed towards more conventional approaches. Radical approaches or innovations are often seen to be co-opted into old patterns, and realign with, rather than challenge, existing trajectories and power dynamics (Blythe et al., 2018; Fazey et al., 2018; Kläy et al., 2015).

Although change and innovation are encouraged as a central part of managerialism in universities (Barberis, 2012), the trajectory and boundaries of change are determined by unaccountable forces (e.g., philanthropic foundations, market forces, the European Commission). Ultimately this points us back to the managerialist framework (the canvas) that encourages the production of checklists and simplified results that can be easily operationalized, and discourages the nuanced complexities of political realities and social differentiation (Blythe et al., 2018; Scoones, 2009). Therefore, if originality, a willingness to deviate from norms, and explorative thinking that deviates from traditional paths are the essence of CMs (Kara, 2015; Richards, 2010) the approach of individual researchers is not the only thing that needs to become more creative. It is more importantly the creative approach to the organization and funding of knowledge production in universities, and the processes through which their roles in society are negotiated, that must be challenged. Since we have identified de-politicization (i.e., control and sterilization of the public debate) as the crucial barrier to creativity and CM, the next section spells out in more detail the particular value characteristics of control that we believe should be confronted.

\section{The Values of Managerial Knowledge Production}

\section{Don't Bite the Hand that Funds You}

As Bavington (2002) has shown, the roots of the word "management" stem back to the Italian word maneggiare, which in the sixteenth century 
originally referred to the rearing of wild horses. Likewise, we have defined the managerial university as rooted in control-keeping research and higher education on a leash, and ultimately marginalizing meaningful dissent in the public sphere. The process of bringing managerial practices and values into universities has been sustained by four major driving forces: an environment of funding scarcity; a logic of competition to secure funding; the implementation of accountability metrics to rank competitors; and the creation of incentives for obedience. In looking closer at these forces, this section will explain more specifically how control is maintained. We do this by deconstructing the narratives used to justify New Public Management (NPM) reform, and providing evidence to suggest that these reforms are, in essence, about keeping academia on a leash.

Managerialism has relied on a marketization approach to funding public institutions that is consistent with general NPM reforms (Irzik, 2007; Palumbo \& Scott, 2018). In this approach, universities act as corporations in a competitive market, instead of functional parts of a whole (Connell, 2019). This has made competing to maximize -or at least maintain-access to resources the driving organizational force of university governance (Palumbo \& Scott, 2018). The market-based approach has fostered a culture of ruthless competition for academics among and against each other in order to fund their work (and consequently, their economic survival). In order to rank the competitors and determine who would receive funding, managers from states, supranational institutions, and university administrations have standardized the measurement of individual academic and university performance (Lynch, 2015). Muller (2018) refers to the resulting system as a "tyranny of metrics": a faith in objective and quantifiable measurability as a replacement for subjective and qualitative human judgement. The tyranny of metrics can also be described with what Deem et al. (2007) have described as an "institutionalized distrust", rooted in a pervasive suspicion that seeks to strictly monitor staff, curtail their room for autonomy and improvisation, and have them constantly justify their work and activities (Adler \& Borys, 1996; Graeber, 2018). As we have stated above, the claim that such "objective" measurements are devoid of social values is illusory (cf. Sayer, 2011). 
These metrics are, in fact, defined from above in line with the values and material interests of states, supranational institutions, corporations, and private philanthropic foundations who have the capacity to allocate grants and other resources to fund research. While funding institutions may claim impartiality, a closer look shows that many-private foundations and corporations in particular-are not as politically neutral as they may purport (Lynch, 2015). Apart from governments, none of these institutions are subjected to democratic control, and may be driven by private interests that are indifferent or even antithetical to public or common interests (Irzik, 2007). The lack of oversight for these funding institutions is particularly concerning in the case of private philanthropic foundations. Private foundations have been described as "black boxes", immune from public oversight, with largely unrestricted "hyper-agency"-i.e., "the ability to shape socio-political frameworks and matrices in which networked governance occurs" (Jung \& Harrow, 2015 , p. 49). It is argued that many of these private foundations are driven by "philanthro-capitalism" (Garcia-Arias, 2019; Mediavilla \& Garcia-Arias, 2019; Silver, 1998). In this sense, the hyper-agency of philanthropists can be used as a sort of masked lobbying. ${ }^{4}$ That is, facilitating the production of knowledge that is ostensibly in the public interest, but is primarily driven by private agendas. The opaque nature of foundations allows them to bypass society's democratic structures and advance an "economic model of investment and political model of control" under the guise of generosity (Shiva \& Shiva, 2018, p. 120). One example is the Bill and Melinda Gates Foundation, which funds research and development programmes for public health and agriculture around the world to the tune of billions of dollars per year (Biovision Foundation for Ecological Development and IPES-Food, 2020; McCoy et al., 2009; Shiva, 2016). The foundation's approach to funding research leads to the promotion of certain paradigms (e.g., centralized industrial agriculture, privatization of medical systems, etc.) at the expense of others (see also Vanloqueren \& Baret, 2009). In fact, all funding institutions exert some measure of control over science policy and research

\footnotetext{
${ }^{4}$ See for example the arguments of the Reese Committee investigation of tax-exempt foundations in the United States in the 1950s (Gideonse, 1954).
} 
content (Gläser \& Laudel, 2016). Funders effectively hold the reins of control to direct society's production of knowledge and are the factual managers of the managerial university (Lynch, 2015).

In line with corporate governance, which aims to give shareholders more control over management, funders exert their control through top-down monitoring and assessment. This has a disciplinary effect on dissent for academic staff, in line with the old adage, "don't bite the hand that feeds you". It creates barriers to levying independent foundational critiques of funding institutions (Pusser et al., 2011), and incentivizes and selects for the perpetuation of dominant ideological paradigmse.g., those in power within the current system self-select for those who share their worldview and values (Mitchell \& Fazi, 2017). This perpetuation is further reinforced by a growing "reserve army" of precarious academic labourers (e.g., PhDs and post-docs) who work on short-term contracts without job security (cf. Ginsberg, 2011). While the numbers of these precarious labourers continue to grow by many estimates (e.g., the number of doctoral graduates in OECD countries grew by $40 \%$ from 2000-2009), the secure and tenured positions do not (Worms \& Boman, 2017). Academic labour, in turn, becomes devalued and easily replaceable, creating a further incentive for staff to toe the line in a positional competition game, or to simply take their skills to the (corporate) private sector where earning potentials are higher, or at least more secure.

Three main rationalizations are used to justify NPM reforms promoting accountability and competition. First, they are said to foster societal engagement and innovation by eliminating freeriding privileges for "ivory tower" academics with tenure. In this narrative, NPM reforms are carried out in order to provide more value for the taxpayer who assumes the role of shareholder. Value is understood in economic terms as a return on investment (Halffman \& Radder, 2015), and science is evaluated based on its ability to facilitate the creation of wealth or jobs (Jasanoff, 2005). However, instead of eliminating privileges for "freeloaders", such collaborations have created a new set of privileges for (corporate) actors in the military-industrial-academic complex. These private actors - unbeholden to any notion of the public good or wider social responsibilities - have in turn been able to leverage their funding capacities and therefore outsource the risk of research and development 
(R\&D) to publicly subsidized universities, while privatizing the benefits (Mazzucato, 2011; Palumbo \& Scott, 2018; Schugurensky, 2006). A prime example of this is the US Bayh-Dohl Act (1980) that allowed inventions discovered with public funds to be patented for private gain (Irzik, 2007). In effect, this has created a system of technology transfer from the public to the private sector (ibid.; cf. Mazzucato, 2011) under the guise of ostensible "societal engagement".

Another argument for the reforms is that they control for quality in research. In reality, there is evidence to suggest that the opposite is true. Competition has actually led to a race to the bottom: spreading the work of academics increasingly thin, subjecting them to higher levels of stress and anxiety, and therefore negatively impacting the quality of their work (Berg, 2015). While any person may win the competition of being the best scholar, not every person can win this competition. The zero-sum logic of competition (again not only for prestige, but also for institutional funding, and economic survival of individual researchers) requires the acceptance that while some may win the competition, others will lose. Obviously, this is not a new dynamic, as any attempt to make use of limited resources (e.g., funding, job positions) involves a certain degree of competition. What we are highlighting are the dangers of placing competition as a core principle of academic life. For example, a survey of more than four thousand UK academics conducted by the Wellcome Trust showed that only $32 \%$ of respondents agreed that "healthy competition" was encouraged in their working environment, while $78 \%$ agreed that competition had created unkind and aggressive research conditions (Wellcome Trust, 2020).

Managerialism has accelerated the trend of relentless competition, the influence of which has been multiplied by the increasing hordes of a "reserve army" of junior academic staff. With the introduction of these high stakes, academics are incentivized to produce scientific knowledge at an increasingly rapid pace in order to stand out from their competitors. Today, the average academic publishes approximately six times as many papers as if they were working a century ago (Larsen \& von Ins, 2010). This increased production has come with a detriment to the substance of scientific output. The phenomenon has been referred to as "scientific salami slicing" (Ding et al., 2019); this describes how academics separate 
research articles into the "minimum publishable unit" with the goal of maximizing the number of publications they can achieve from the same study (cf. Halffman \& Radder, 2015). Moreover, duplicate publications are also common practice. A recent study shows that up to $20 \%$ of new publications in certain fields of research have reported the same results as in previous publications (Lai et al., 2020). Rather than sharpening quality, managerial reforms have engendered a situation where "knowledge" is overproduced. Is the latest article motivated by a piercing new insight? A novel contribution to knowledge? Or is it intended to pad the author's curriculum vitae due the coming expiration of their temporary contract? Ultimately, this overproduction devalues quality work by leaving researchers to search for the needle of quality in a seemingly infinite haystack of overproduced publications. A prime example (but by no means the only example) is the journal Sustainability. At the time of writing, the journal has planned over 150 special issues for 2021 alone, and in 2018 had more than 200.5 Standard issues, which in 2019 were bi-monthly, often include more than 500 articles. Additionally, at the time of writing the "Article Processing Charge" for Sustainability was more than $€ 1,700$ per paper. This fantastic amount of papers could hardly be thoroughly digested by even the most astute of readers who is interested in keeping up on all of the latest debates in sustainability and sustainable development.

One is left to wonder, who and what are all these papers for? What is actually motivating their authorship and publication?

According to a blog post from Arjen Wals (2019), a sustainability researcher in the Netherlands, contemporary academia's publish or perish culture has led to a troubling paradox, in which "everybody is writing while nobody seems to be reading, really, which means that everybody is writing for nobody". This, in our view, is a race to the bottom: the illogical result of a university system based on managerial values and practices that incentivize quantity of publications over quality, and facilitate the commodification of publicly funded knowledge for private accumulation of profit.

\footnotetext{
5 See: https://www.mdpi.com/journal/sustainability/special_issues?page_count=100\&page_no= 31\&search=\&section_id=0\&sort=deadline\&view=open (Accessed 26 Feburary, 2021).
} 
Finally, reforms have been justified on the basis that they produce efficiency. However, there is (even more) evidence to suggest that many of the outcomes have been quite inefficient. Academic staff are subjected to a great number of "box-ticking" rituals in which they must constantly assess and justify their own work (Graeber, 2018). This can result in a paradox in which more university time and resources are allocated to monitoring and applying for further funding, than in doing actual research and education. For example, one study in the Netherlands estimated that approximately one quarter of the research budget for a federal subsidy programme for Dutch universities is spent on "overheads of writing, reviewing, and allocating" applications for the budget itself (Halffman \& Radder, 2015, p. 169). "Ironically", under the tyranny of metrics, Muller (2018, p. 75) emphasizes, "in the name of controlling costs, expenditures wax". Following a recent study, European universities spend approximately $€ 1.4$ billion every year to fund failed grant applications. ${ }^{6}$ If efficiency is the goal, would it not actually be more expedient to make resources available to responsible and autonomous academics in the first place?

To conclude, the expansion of competition has found fertile ground in shrinking public budgets and precarious funding conditions for students and employees. These dynamics have been reinforced by a standardized accountability system that rewards obedience and filters out dissent through groupthink and fear of being replaced. The managerial university relies on a simplification of parameters to quantify research output, which ends up prioritizing quantity over quality. Time consuming and thorough investigations of complex issues are devalued, as scholars are encouraged to "publish or perish". For academics, we argue that these values encourage what Graeber (2018) has called "forced creativity". The danger of forced creativity is that, while CMs may be different on the surface, they fail to break from the chains of the institutional context within which they operate, leaving their creativity forced, and substantively hollow. Although research activities have been extended to involve actors outside of academia, the pursuit of unspecified impact can come

\footnotetext{
${ }^{6}$ https://www.timeshighereducation.com/news/billions-lost-in-bids-to-secure-european-union-res earch-funding (Accessed 26, Feburary, 2021).
} 
with undesirable consequences, which have hardly been recognized and studied as a result of more action-oriented research projects (Louder et al., 2021). The problem starts from the profoundly diverse (and often not explicitly stated) epistemic assumptions and what counts as impact (ibid). However, under pressure to avoid failure (Davies et al., 2021), and achieve the maximum impact of measurable output, academics may be led to blindly chase any kind of creativity that sets them apart, without asking important questions such as "who benefits and loses [...] and how this can be justified" (Turnhout, 2018, p. 368). In other words, as the individual researcher strives to survive in an increasingly demanding and competitive "industry", the risk is that their mobilization of creative methods exacerbates the problems they intend to address, rather than providing a solution.

Now that we have sketched out our critical analysis of the managerial university and its role in suppressing open democratic politics, we will look closer at the prospect of bringing creativity into the research process in the confines of the managerial university.

\section{The Danger of Forced Creativity}

\section{Latent Risks in Creative and Arts-Based Methods}

Michel Foucault famously explained that the point of his critique was not that "everything is bad", but rather that "everything is dangerous" (cited in Galliers et al., 2011, p. 177). Likewise, our message here is not that CMs are inherently bad. It is rather that, especially in the context of the managerial university we outlined above, CMs are dangerous: their use can be co-opted into a coercive maintenance of the status quo, as much as they can to liberating empowerment. In order to raise awareness about the dangers, we provide two practical examples of forced creativity. In doing so, we intend to outline the major risks of which researchers thinking of using CMs should be aware. 


\section{Artwashing}

Much like the "greenwashing" tactics employed by corporate polluters (Athanasiou, 1996), artwashing is a de-politicizing strategy that may be used by powerful actors to manage and placate discontent by giving a "cool" and "artsy" appearance to elite agendas (Novak, 2019). One example is Florida's (2005) "creative class" concept, in which arts and creativity were used to generate a positive vibe for elite development projects that drive gentrification, privatization and marketization of urban space (Ruck, 2020). Similarly, the work of researchers who use CMs may (unintentionally) be appropriated to give a favourable "spin" to potentially unpopular messages of management (Barberis, 2012, p. 330).

Artwashing can also be used to give symbolic recognition to communities, while obscuring deeper foundations of their disempowerment. Mirroring Nancy Fraser's notion of "progressive neoliberalism", CMs may contribute to superficial recognition (surface reallocations of respect), while masking inequalities of distribution (share of material resources), and representation (share of decision-making and political equality) that also contribute to disempowerment (Fraser, 2005, 2016). As researchers use CMs to bring recognition to the struggles of communities, they run the risk of subjecting communities to a form of "tokenism" (Arnstein, 1969), which gives an illusory appearance of participation and inclusion. Instead of drawing attention to the root causes of community disempowerment, under the pretence of using CMs researchers may nominate themselves as a spokesperson for communicating community needs and desires (Kouritzin \& Nakagawa, 2018). This hierarchical positioning can put the researched community into a subordinate level of representation, with the risk that their demands are interpreted in line with the researcher's positionality. Namely, this can create an extractive relationship between the researcher and the community, in which the experiences and actions of the community are used as a resource to advance the career of the researcher, while the goal of amplifying voices becomes secondary.

This "empowerment without power" is a direct consequence of depoliticization, as critical questioning of the social and ecological relationships that determine undemocratic representation and detrimental 
material conditions are left out of the picture. An a-critical use of CMs runs the risk of aestheticizing community members in their present state, leaving them embalmed rather than providing them with the means to emancipate themselves in the future. In an environment where the underlying goal of research that uses CMs is likely to be focused on quantitative personal academic career development (e.g., citations), such extractive tendencies are an ever present risk.

\section{Funding Tricks}

External funding conditions in the larger political economy described above often come with an imperative of constant innovation, novelty, and adjustment (Palumbo \& Scott, 2018). Funding tricks, in which creativity is performed for the sake of helping one stand out in comparison to other funding applicants, are an inevitable danger of responding to these incentives. Moreover, as funding calls mostly require that applicants fit within a format that is predetermined by funders who expect certain outcomes, funding tricks are particularly prone to propagating forced creativity.

The research funding strategy of the European Commission, through the European Research Council (ERC), is a good illustration of this. Access to funding is granted according to a specific jargon and sophisticated rules. This creates incentives for the formation of a specialized body of experts whose aim is not to write meaningful research applications, but to work as intermediaries between the source of the funding and the researcher. This incentivizes the production of "nice-sounding" proposals that embellish and "dress up" business as usual responses to funding calls (cf. Cornwall \& Brock, 2005). If one must "sell" their research proposal in order to avail in competition, they are incentivized to employ deceptive tactics used by marketers or public relations firms (Frankfurt, 2009). This practice is common enough that it has found expression in at least two European languages. A German word, Förderantragsjargon (funding application jargon), describes the practice of creating token participation in response to the EU's Smart City funding calls (the EU requires participation, so applicants include it in the proposal without the intent of 
actually incorporating it) (Follmann et al., 2020). An Italian term, europrogettazione, in use since the late 1990s, describes a specific discipline that literally translates into "European project-making".

Several higher education courses are nowadays available for those who want to master the litanies of EU funding applications. When the content of the research has a similar or even secondary relevance compared to the jargon used to present it, forced creativity may grow in the guise of CMs. It is the stratified governance of highly bureaucratic organizations such as the EU that is inevitably entailing a certain degree of resistance to innovation (Banchoff, 2002). This institutional inertia creates niches of privilege. This is what Hoenig (2017) defines the "new scientific elite", which emerges according to centre-periphery-structures due to historical path-dependency and accumulation of knowledge in certain geopolitical locations.

\section{Conclusions}

"[...] if 'the revolution will not be televised', it certainly won't be peerreviewed”. (Davies et al., 2021, p. 5). So far, we have offered a critical review of the managerial university, its embedded values, and the dangers of employing creative methods (CMs) in such an environment. As we noted at the beginning of this chapter, CMs have been framed as an individual responsibility of a researcher, to fulfil the new multi-faceted role of knowledge producer, knowledge translator, communicator, codesigner, and implementers of action (Freeth et al., 2019; Horlings et al., 2020; Wittmayer \& Schäpke, 2014). Although individual reflexivity and understanding one's own normative position as a moral and political agent in a changing world may be crucial, we ask for understanding $\mathrm{CM}$ in the light of the greater structures of academia. We wish to stress that the picture we have highlighted is one of a collective problem that cannot be addressed through a purely individual struggle. An understanding of the wider context-which we referred to earlier as the "canvas" on which researchers "paint" - and a willingness to creatively transgress established academic structures and protocols (Temper et al., 2019) are of utmost importance if we as academics wish to move towards 
truly creative academic practice while avoiding the latent risks of forced creativity. In other words, one cannot be truly creative in a transgressive manner if one does not know exactly what they are transgressing. Transgression of the managerial university that enables an environment of creativity will have to include various radical interventions into its sustaining forces-namely, funding, competition, and obedience.

In preparing this chapter, both in conceiving it and drafting it, we were further persuaded by several one-on-one discussions with scholars who, despite coming from very different contexts and backgrounds, described the same feeling of working in a deteriorating environment where much of their activity made little sense (see also Berg (2015) who conveys a similar experience in the long process of writing his critical article on neoliberalization of universities). For us, the awareness that we are not alone in feeling somewhat lost and hopeless in the halls of the managerial university is comforting and empowering. This more realistic, even stoic understanding of the institutional setting can give young researchers who may be looking to engage in heterodox and transformative approaches a more coherent picture of what they are up against. By no means do we wish to chastise the individuals who are not willing to engage in this struggle. But we do hope that other young academics who are disillusioned by their institutional environments dedicate themselves to further political action and coalition-building beyond the constraints of the managerial university.

Acknowledgements This research received funding from the European Union's Horizon 2020 research and innovation programme under the Marie Sklowdoska-Curie Grant Agreement No. 765389.

\section{References}

Adler, P. S., \& Borys, B. (1996). Two types of bureaucracy: enabling and coercive. Administrative Science Quarterly, 41, 61-89.

Adler, P. S., Forbes, L. C., \& Willmott, H. (2007). Critical Management Studies, $1-61$. 
Anderson, G. (2008). Mapping academic resistance in the managerial university. Organization, 15, 251-270. https://doi.org/10.1177/135050840708 6583

Arendt, H. (1958). The human condition (2nd ed.). The University of Chicago Press.

Arnstein, S. R. (1969). A ladder of citizen participation. Journal of the American Institute of Planners, 35, 216-224. https://doi.org/10.1080/019443669089 77225

Athanasiou, T. (1996). The age of greenwashing. Capitalism Nature Socialism, 7, 1-36.

Banchoff, T. (2002). Institutions, inertia and European union. Research Policy, $40,1-21$.

Barberis, P. (2012). The managerial imperative: Fifty years' change in UK public administration. Public Policy Administration, 28, 327-345. https:// doi.org/10.1177/0952076712458789

Bavington, D. (2002). Managerial ecology and its discontents: Exploring the complexities of control, careful use and coping in resource and environmental management. Environments, 30, 3-22.

Berg, L. D. (2015). Rethinking the $\mathrm{PhD}$ in the age of neoliberalization. GeoJournal, 80, 219-224. https://doi.org/10.1007/s10708-014-9574-6

Biovision Foundation for Ecological Development, IPES-Food. (2020). Money flows: What is holding back investment in agroecological research for Africa? Biovision Found. Ecol. Dev. Int. Panel Expert. Sustain. Food Syst.

Blythe, J., Silver, J., Evans, L., Armitage, D., Bennett, N. J., Moore, M.-L., Morrison, T. H., \& Brown, K. (2018). The dark side of transformation: Latent risks in contemporary sustainability discourse. Antipode, 50, 12061223. https://doi.org/10.1111/anti.12405

Bregman, R. (2017). Utopia for realists: And how we can get there. Bloomsbury. Bronowski, J. (1985). Science as a humanistic discipline. Leonardo, 18, 261. https://doi.org/10.2307/1578078

Bronowski, J. (1968). The creative process. Journal of Creative Behaviour, 2, 63-70. https://doi.org/10.1002/j.2162-6057.1968.tb00083.x

Bronowski, J. (1956). Science and human values. Julian Messner.

Bronowski, J., Steele Commager, H., Allport, G., \& Buck, P. (Eds.). (1964). Imagination and the university. University of Toronto Press.

Brown, W. (2010). Political theory is not a luxury: A response to Timothy Kaufman-Osborn's “political theory as a profession.” Political Research Quarterly, 63, 680-685. https://doi.org/10.1177/1065912910369843 
Bullen, E., Robb, S., \& Kenway, J. (2004). "Creative destruction”: Knowledge economy policy and the future of the arts and humanities in the academy. Journal of Educational Policy, 19, 3-22. https://doi.org/10.1080/026809304 2000182609

Chauvière, M., \& Mick, S. (2013). The French sociological critique of managerialism: Themes and frameworks. Critical Sociology, 39, 135-143.

Chomsky, N. (2000). Rogue state. South End Press.

Chomsky, N. (2008). The responsibility of intellectuals. In A. Arnove (Ed.), The essential chomsky. The New Press.

Chomsky, N. (2012). Democracy and Education. Counterpoints, 422, 55-70. https://doi.org/10.1017/CBO9781107415324.004

Clark, W. C. (2016). Crafting usable knowledge for sustainable development. Proceedings of the National Academy of Sciences, 113, 4570-4578.

Connell, R. (2019). The good university: What universities actually do and why it's time for radical change. Zed Books Ltd.

Cornwall, A., \& Brock, K. (2005). What do buzzwords do for development policy? A critical look at "participation", "empowerment" and "poverty reduction.” Third World Quaterly, 26, 1043-1060. https://doi.org/10.1080/ 01436590500235603

Cruikshank, B. (1999). The will to empower. Cornell University Press.

Davies, T., Disney, T., \& Harrowell, E. (2021). Emotion, space and society reclaiming failure in geography: Academic honesty in a neoliberal world. Emotion Space and Society, 100769. https://doi.org/10.1016/j.emospa.2021. 100769

Deem, R. (2001). Globalisation, new managerialism, academic capitalism and entrepreneurialism in universities: Is the local dimension still important? Comparative Education, 37, 7-20. https://doi.org/10.1080/030500600200 20408

Deem, R., \& Eggins, H. (Eds.). (2017). The university as a critical institution?, Higher education research in the 21st century Series. Sense Publishers. https:// doi.org/10.1017/CBO9781107415324.004

Deem, R., Hillyard, S., \& Reed, M. (2007). Knowledge, higher education and the new managerialism: The changing management of $U K$ universities. Oxford Univeristy Press.

Ding, D., Nguyen, B., Gebel, K., Bauman, A., \& Bero, L. (2019). Duplicate and salami publication: A prevalence study of journal policies. International Journal of Epidemiology, 49, 281-288. https://doi.org/10.1093/ije/dyz187 
Evans, M. (2020). Navigating the neoliberal university: Reflecting on teaching practice as a teacher-researcher-trade unionist. British Journal of Sociology of Education, 41, 574-590. https://doi.org/10.1080/01425692.2020.1748572

Fazey, I., Schäpke, N., Caniglia, G., Patterson, J., Hultman, J., van Mierlo, B., Säwe, F., Wiek, A., Wittmayer, J., Aldunce, P., Al Waer, H., Battacharya, N., Bradbury, H., Carmen, E., Colvin, J., Cvitanovic, C., D’Souza, M., Gopel, M., Goldstein, B., ... Wyborn, C. (2018). Ten essentials for actionoriented and second order energy transitions, transformations and climate change research. Energy Research \& Social Science, 40, 54-70. https://doi. org/10.1016/j.erss.2017.11.026

Florida, R. (2005). Cities and the Creative Class. Routledge.

Follett, M. P. (1930). Creative experience. Longmans, Green and Co.

Follmann, A., Leitheiser, S., \& Kreitschmer, H. (2020). Smart und oder participativ? Eine kritische Betrachtung der Smart City Cologne (forthcoming). sub/urban.

Frankfurt, H. G. (2009). On bullshit. Princeton University Press.

Fraser, N. (2005). Reframing justice in a globalizing world. New Left Review, $36,69-88$.

Fraser, N. (2016). Progressive neoliberalism versus reactionary populism: A Choice that Feminists Should Refuse. NORA-Nordic Journal of Feminist and Gender Research, 24, 281-284. https://doi.org/10.1080/08038740. 2016.1278263

Freeth, R., Clarke, E. A., \& Fam, D. (2019). Engaging creatively with tension in collaborative research. In A. Valerie, John A. Brown \& D. W.-T. Harris (Ed.), Independent thinking in an uncertain world. Routledge.

Galliers, R., Currie, W., Willcocks, L., \& Lioliou, E. (2011). 'Everything is dangerous': Rethinking Michel Foucault and the social study of ICT. In R. D. Galliers \& W. L. Currie (Eds.), The oxford handbook of management information systems: Critical perspectives and new directions. Oxford University Press.

Garcia-Arias, J. (2019). A critical perspective on development economics philanthrocapitalism: How to legitimize the hegemony of the rich with a "good vibes" discourse.

Gibson-Graham, J. K., Cameron, J., \& Healy, S. (2013). Take back the economy: An ethical guide for transforming our communities. University of Minnesota Press.

Gideonse, H. D. (1954). A congressional committee's investigation of the foundations. Journal of Higher Education, 25, 457-463.

Ginsberg, B. (2011). The fall of the faculty. Oxford University Press. 
Giroux, H. A. (2015). University in chains: Confronting the military-industrialacademic complex. Routledge.

Giroux, H. A. (2010). Bare pedagogy and the scourge of neoliberalism: Rethinking higher education as a democratic public sphere. The Educational Forum, 74, 184-196. https://doi.org/10.1080/00131725.2010.483897

Giroux, H. A. (2009). Democracy's nemesis: The rise of the corporate university. Cultural Studies_Critical Methodologies, 9, 669-695. https://doi.org/ $10.1177 / 1532708609341169$

Gläser, J., \& Laudel, G. (2016). Governing science: How science policy shapes research content. European Journal of Sociology, 57, 117-168. https://doi. org/10.1017/s0003975616000047

Goodwyn, L. (1978). The populist moment: A short history of the agrarian revolt in America. Oxford University Press.

Graeber, D. (2018). Bullshit jobs: A theory. Simon \& Schuster.

Habermas, J. (1990). Strukturwandel der Öffentlichkeit. Suhrkamp Verlag.

Halffman, W., \& Radder, H. (2015). The academic manifesto: From an occupied to a public university. Minerva, 53, 165-187. https://doi.org/10.1007/ s11024-015-9270-9

Hansson, S. O. (2004). Seven Myths of Risk. Risk Management, 7, 7-17.

Harré, R. (1981). Philosophical aspects of the micro-macro problem. In K. Knorr-Cetina \& A. V. Cicou-rel (Eds.), Advances in social theory and methodology: Towards an integration of micro and macro sociologies. Routledge and Kegan Paul.

Hoenig, B. (2017). Europe's new scientific elite: Social mechanisms of science in the European research area, Europe's new scientific elite: Social mechanisms of science in the European research area. Taylor and Francis. https://doi.org/10. 4324/9781315446042

Holmwood, J. (2017). The university, democracy and the public sphere. British Journal of Sociology of Education, 38, 927-942. https://doi.org/10.1080/014 25692.2016.1220286

Hölscher, K., Wittmayer, J. M., Avelino, F., \& Giezen, M. (2017). Opening up the transition arena: An analysis of (dis)empowerment of civil society actors in transition management in cities. Technological Forecasting and Social Change, 0-1. https://doi.org/10.1016/j.techfore.2017.05.004

Horlings, L. G., Nieto-Romero, M., Pisters, S., \& Soini, K. (2020). Operationalising transformative sustainability science through place-based research: The role of researchers. Sustainability Science, 15, 467-484. https:// doi.org/10.1007/s11625-019-00757-x 
Irzik, G. (2007). Commercialization of Science in a Neoliberal World. In A. Bugra \& K. Agartan (Eds.), Reading Karl Polanyi for the twenty-first century: Market economy as a political project (pp. 135-153). Palgrave Macmillan.

Jasanoff, S. (2005). Designs on nature: Science and democracy in europe and the United States. Princeton University Press.

Jung, T., \& Harrow, J. (2015). New development: Philanthropy in networked governance-Treading with care. Public Money Management, 35, 47-52. https://doi.org/10.1080/09540962.2015.986880

Kara, H. (2015). Creative research methods in the social sciences: A practical guide. Policy Press.

Kates, R., Clark, W., Corell, R., Hall, C., \& Lowe, I. (2001). Sustainability science. Science, 292(5517), 641-642.

Kläy, A., Zimmermann, A. B., \& Schneider, F. (2015). Rethinking science for sustainable development: Reflexive interaction for a paradigm transformation. Futures, 65, 72-85. https://doi.org/10.1016/j.futures.2014.10.012

Klikauer, T. (2015). What is managerialism? Critical Sociology, 41, 1103-1119. https://doi.org/10.1177/0896920513501351

Kouritzin, S., \& Nakagawa, S. (2018). Toward a non-extractive research ethics for transcultural, translingual research: Perspectives from the coloniser and the colonised. Journal of Multilingual and Multicultural Development, 39, 675-687. https://doi.org/10.1080/01434632.2018.1427755

Labaree, D. F. (2010). How Dewey lost: The victory of David Snedden and social efficiency in the reform of American education. In D. Tröhler, T. Schlag \& F. Osterwalder (Eds.), Pragmatism and modernities (pp. 163-188). Sense Publishers.

Lai, C., Sbidian, E., Giraudeau, B., \& Le Cleach, L. (2020). Twenty percent of secondary publications of randomized controlled trials of drugs did not provide new results relative to the primary publication. Journal of Clinical Epidemiology, 117, 20-28. https://doi.org/10.1016/j.jclinepi.2019.09.012

Larsen, P. O., \& von Ins, M. (2010). The rate of growth in scientific publication and the decline in coverage provided by science citation index. Scientometrics, 84, 575-603. https://doi.org/10.1007/s11192-010-0202-z

Leišyte, L. (2015). Changing academic identities in the context of a managerial university: Bridging the duality between professions and organizations. In W. Cummings \& U. Teichler (Eds.), The relevance of academic work in comparative perspective (pp. 59-73). Springer.

Longino, H. (1990). Science as social knowledge. Princeton University Press.

Louder, E., Wyborn, C., Cvitanovic, C., \& Bednarek, A. T. (2021). A synthesis of the frameworks available to guide evaluations of research impact 
at the interface of environmental science, policy and practice. Environmental Science \& Policy, 116, 258-265. https://doi.org/10.1016/j.envsci. 2020.12.006

Lynch, K. (2015). Control by numbers: New managerialism and ranking in higher education. Critical Studies in Education, 56, 190-207.

Mazzucato, M. (2011). The entrepreneurial state. Demos.

McCoy, D., Kembhavi, G., Patel, J., \& Luintel, A. (2009). The bill \& Melinda Gates foundation's grant-making programme for global health. Lancet, 373, 1645-1653. https://doi.org/10.1016/S0140-6736(09)60571-7

Mediavilla, J., \& Garcia-Arias, J. (2019). Philanthrocapitalism as a neoliberal (development agenda) artefact: Philanthropic discourse and hegemony in (financing for) international development*. Globalizations, 16, 857-875. https://doi.org/10.1080/14747731.2018.1560187

Miller, T. R. (2013). Constructing sustainability science: Emerging perspectives and research trajectories. Sustainability Science, 8, 279-293.

Mitchell, W., \& Fazi, T. (2017). Reclaiming the state: A progressive vision for sovereignty for a post-neoliberal world. Pluto Press.

Mouffe, C. (1992). Democratic citizenship and the political community. In C. Mouffe (Ed.), Dimensions of radical democracy: Pluralism, citizenship, community (pp. 225-239). Verso. https://doi.org/papers2://publication/uuid/9C7 39CCF-6B42-483C-AA66-B35CF7D2FA6E

Mouffe, C. (2005). On the political. Routledge.

Mould, O. (2018). Against creativity. Verso.

Muller, J. Z. (2018). The tyranny of metrics. Princeton University Press.

Nagatsu, M., Davis, T., DesRoches, C. T., Koskinen, I., MacLeod, M., Stojanovic, M., \& Thorén, H. (2020). Philosophy of science for sustainability science. Sustainability Science, 15, 1807-1817. https://doi.org/10. 1007/s11625-020-00832-8

Novak, D. (2019). The arts of gentrification: Creativity, cultural policy, and public space in Kamagasaki. City and Society, 31, 94-118. https://doi.org/ $10.1111 /$ ciso. 12195

Palumbo, A., \& Scott, A. (2018). Remaking market society: A critique of social theory and political economy in neoliberal times. Routledge.

Pettigrew, A. M., Cornuel, E., \& Hommel, U. (Eds.). (2014). The institutional development of business schools. Oxford Scholarship Online.

Popper, K. R. (1979). Objective knowledge: An evolutionary approach. Oxford University Press. 
Pusser, B., Kempner, K., Marginson, S., \& Ordorika, I. (Eds.). (2011). Universities and the public sphere: Knowledge creation and state building in the era of globalization. Routledge.

Richards, R. (2010). Everyday creativity: Process and way of life- Four key issues. In J. C. Kaufman \& R. J. Sternberg (Eds.), The cambridge handbook of creativity (pp. 189-215). Cambridge University Press.

Ruck, A. (2020). Artwashing Education? International Journal of Art \& Design Education, 39, 405-417. https://doi.org/10.1111/jade.12290

Sayer, A. (2011). Why things matter to people: Social science. Cambridge University Press.

Schrum, E. (2012). To "administer the present": Clark Kerr and the purpose of the postwar American research university. Social Science History, 36, 499523. https://doi.org/10.1215/01455532-1717154

Schugurensky, D. (2006). The political economy of higher education in the time of global markets: whither the social responsibility of the university? In R. Rhoads \& C. Torres (Eds.), The university, state, and market: The political economy of globalization in ThSe Americas. Stanford University Press.

Scoones, I. (2009). Livelihoods perspectives and rural development. Journal of Peasant Studies, 36, 171-196.

Scott, J. C. (1998). Seeing like a state: How certain schemes to improve the human condition have failed. Yale University Press.

Shepherd, S. (2018). Managerialism: An ideal type. Studies in Higher Education, 43, 1668-1678. https://doi.org/10.1080/03075079.2017.1281239

Shiva, V. (2016). Who really feeds the world? North Atlantic Books.

Shiva, V., \& Shiva, K. (2018). Oneness vs. the 1\%: Shattering illusions, seeding freedom. Spinifex Press.

Shrivastava, P., Stafford Smith, M., O’Brien, K., \& Zsolnai, L. (2020). Transforming sustainability science to generate positive social and environmental change globally. One Earth, 2, 329-340. https://doi.org/10.1016/j.oneear. 2020.04.010

Silver, I. (1998). Buying an activist identity: Reproducing class through social movement philanthropy. Sociological Perspectives, 41, 303-321.

Swyngedouw, E. (2018). Promises of the political: Insurgent cities in a postpolitical environment. The MIT Press.

Temper, L., McGarry, D., \& Weber, L. (2019). From academic to political rigour: Insights from the 'Tarot' of transgressive research. Ecological Economics, 164. https://doi.org/10.1016/j.ecolecon.2019.106379

Tierney, W. G., \& Lechuga, V. M. (2005). Academic Freedom in the 21 st Century. Thought \& Action, 7-22. 
Turnhout, E. (2018). The politics of environmental knowledge. Conservation and Society, 16, 363-371. https://doi.org/10.4103/cs.cs

Vanloqueren, G., \& Baret, P. V. (2009). How agricultural research systems shape a technological regime that develops genetic engineering but locks out agroecological innovations. Research Policy, 38, 971-983. https://doi.org/10. 4324/9781315666396

Wals, A. (2019). Publish AND perish: how the commodification of scientific publishing is undermining both science and the public good [WWW Document]. Learn. Sustain. times Accel. Chang.

Ware, N. (1929). The labor movement in the United States, 1860-1895: A study in democracy. Vintage Books.

Wellcome Trust. (2020). What researchers think about the culture they work In. https://doi.org/10.1042/bio20200032

Wittmayer, J. M., \& Schäpke, N. (2014). Action, research and participation: Roles of researchers in sustainability transitions. Sustainability Science, 9, 483-496. https://doi.org/10.1007/s11625-014-0258-4

Wolin, S. S. (1960). Politics and vision: Continuity and innovation Western political thought. Little, Brown and Company.

Worms, J.-C., \& Boman, J. (2017). The post-doc problem [WWW Document]. European Science Found. https://www.esf.org/news-media/esf-blog/ post/the-post-doc-problem/. Accessed 11 June, 20.

Wright, E. O. (2006). Compass points. New Left Review, 93-124. https://doi. org/10.1016/b978-0-12-374722-8.00035-9 
Open Access This chapter is licensed under the terms of the Creative Commons Attribution 4.0 International License (http://creativecommons.org/ licenses/by/4.0/), which permits use, sharing, adaptation, distribution and reproduction in any medium or format, as long as you give appropriate credit to the original author(s) and the source, provide a link to the Creative Commons license and indicate if changes were made.

The images or other third party material in this chapter are included in the chapter's Creative Commons license, unless indicated otherwise in a credit line to the material. If material is not included in the chapter's Creative Commons license and your intended use is not permitted by statutory regulation or exceeds the permitted use, you will need to obtain permission directly from the copyright holder.

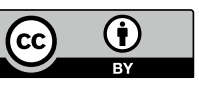

